\title{
Arctic-alpine vegetation biomass is driven by fine scale abiotic heterogeneity
}

\author{
Susanne Suvanto ${ }^{1,2,3}$, Peter C. le Roux ${ }^{1,4}$, Miska Luoto ${ }^{1}$ \\ ${ }^{1}$ Department of Geosciences and Geography, University of Helsinki, Helsinki, Finland \\ ${ }^{2}$ Department of Geoinformatics and Cartography, Finnish Geodetic Institute, Kirkkonummi, \\ Finland \\ ${ }^{3}$ Vantaa Research Unit, Finnish Forest Research Institute, P.O. Box 18, 01301 Vantaa, Finland \\ ${ }^{4}$ Department of Plant Science, University of Pretoria, 0028, Pretoria, South Africa
}

Suvanto, S., le Roux, P.C., Luoto, M., 20xx. Arctic-alpine vegetation biomass is driven by fine scale abiotic heterogeneity. Geografiska Annaler, Series A: Physical Geography, 96, 549-560. doi:10.1111/geoa.12050

ABSTRACT. During recent decades large changes in vegetation biomass have been observed in arctic and alpine areas. While these temporal trends have been clearly linked to changing climatic conditions, the drivers of local spatial variation in biomass are still relatively poorly understood. Thus, we examine the effects of abiotic conditions (as measured by ten variables representing topography, soil properties and geomorphological processes) on variation in aboveground vascular plant biomass to understand the determinants of contemporary fine scale heterogeneity in this variable. We also compare the results from one destructive biomass estimation method (clipharvesting) to three non-destructive biomass estimates: vegetation cover, height and volume. To investigate the local drivers of biomass we analysed an extensive data set of $9601 \mathrm{~m}^{2}$ cells in arctic-alpine tundra using spatially-explicit generalized estimation equations to conduct variation partitioning. The abiotic environment had a clear impact on the fine scale distribution of biomass (variance explained $32.89 \%$ with full model for sampled biomass). Soil properties (temperature, moisture, $\mathrm{pH}$ and calcium content) were most strongly related to aboveground biomass (independent effect in variation partitioning $7.03 \%$ and combined effect including joined effects with topography and geomorphology $19.6 \%$ ). Topography had only a small influence after soil and geomorphology were taken into account (independent effect only $2.23 \%$ and combined effect 18.73 $\%$, implying that topography has only indirect effects on vegetation biomass. Of the three nondestructive biomass estimates, the results for vegetation volume were most similar to those for clipharvested biomass samples. Thus, we recommend utilizing vegetation volume as a cost-efficient and robust non-destructive biomass estimate in arctic-alpine areas. Our results indicate that the fine 
scale environmental variation has to be taken into account more carefully when modelling vegetation biomass and carbon budget, especially under changing climatic conditions.

Keywords: arctic-alpine, biomass, clip-harvesting, topography, vegetation volume

\section{Introduction}

A strong increase in vegetation biomass in arctic and alpine environments has been documented during the last decades (Sturm et al. 2001, Pouliot et al. 2009, Bhatt et al. 2010, Kullman 2010, Elmendorf et al. 2012), with the largest increases in the southernmost arctic tundra (Epstein et al. 2012). This is largely driven by vascular species, and is clearly associated with rising air temperatures (Elmendorf et al. 2012). Given the importance of increasing plant biomass at high latitudes for the global carbon budget (Callaghan et al. 2004, Sitch et al. 2007), understanding the determinants of contemporary biomass patterns is vital for improving predictions of climate change impacts on the high latitude carbon balance under warming conditions. Because local heterogeneity in abiotic conditions is pronounced in many arctic habitats (Shaver et al. 1996, Gould et al. 2003, Shaver et al. 2007, Fletcher et al. 2010), fine scale studies may be most appropriate for characterizing the importance and impacts of abiotic conditions on vegetation biomass.

While biome-scale studies have yielded important insights into vegetation and biomass patterns (e.g. Walker et al. 2003, Epstein et al. 2012, Elmendorf et al. 2012), detailed examination of the fine scale abiotic determinants of vegetation biomass is required due to the pronounced local heterogeneity in abiotic conditions in most arctic habitats (Fletcher et al. 2010). Previous studies in arctic-alpine environments have shown that local topography (Billings 1973, Fisk et al. 1998, Walker et al. 2001), soil properties (Walker et al. 1993, Walker et al. 1994, Fisk et al. 1998, Berdanier and Klein 2011) and earth surface processes (Jonasson 1982, Hjort and Luoto 2009, le Roux and Luoto 2014) have a strong effect on vegetation properties. Local biomass varies along a topographic gradient (Walker et al. 1994, Fisk et al. 1998) and the relationship between topography and biomass is most likely hump-shaped (Litaor et al. 2008), since the growing season length restricts plant growth in depressions (due to late snow melt) and harsh abiotic conditions restrict productivity on exposed ridge tops (Billings 1973, Campioli et al. 2009). Soil properties, especially soil moisture, have been shown to be key factors limiting plant productivity (Walker et al. 1994). In arctic-alpine environments the importance of soil moisture for vegetation appears to be mainly due to its effect on nutrient availability, via its impact on soil microbial activity (Fisk et al. 1998, 
Berdanier and Klein 2011). Geomorphological processes cause physical disturbance, but may also increase soil moisture and nutrient availability, and therefore may have mixed impacts on plant biomass in arctic-alpine environments (Jonasson 1982, Virtanen et al. 2010).

Plant biomass is usually measured as the dry weight of a harvested biomass sample. However, this process is time consuming and destructive (Bobek and Bergström 1978, Axmanova et al. 2012, Redjadj et al. 2012), and in environments with a heterogeneous distribution of biomass, a large number of samples are required for an accurate estimation (Tsutsumi et al. 2007; see also Walker et al. 1994). A time-efficient and non-destructive alternative would therefore be useful (Chen et al. 2009, Axmanova et al. 2012, Redjadj et al. 2012), especially in remote high-latitude and -altitude regions. The simplest alternative measure of biomass is percentage cover of vegetation (e.g. Röttgermann et al. 2000, Krebs et al. 2003, Muukkonen et al. 2006), while a more accurate estimate can be achieved by using vegetation volume that takes into account both vegetation cover and height (Chen et al. 2009, Axmanova et al. 2012).

The aims of this study are (1) to investigate the effects of small scale variation in topography, soil properties and geomorphology on vascular biomass and (2) to test whether the results from three non-destructive biomass estimation techniques (vegetation cover, vegetation height and vegetation volume) differ from those of clip harvesting. Here we do this by analysing an extensive fine scale dataset from arctic-alpine tundra in north-western Finland.

\section{Methods}

\section{Field and laboratory methods}

Data were collected during summer 2011 on the northern slope of the Saana massif, north-western Finland (Fig 1). The study site was approximately $100-200$ meters above the birch (Betula pubescens ssp. czerepanovii) treeline at c. $700 \mathrm{~m}$ a.s.1, and is characterized by shrubs (including Juniperus communis and Betula nana), dwarf-shrubs (Vaccinium spp., Empetrum hermaphroditum) and graminoids (Deschampsia flexuosa, Carex bigelowii). The study design consisted of six 8 x 20 m grids, comprising a total of $9601 \mathrm{~m}^{2}$ cells. The six grids were located inside the area of less than 2 ha to minimize variation in altitude, bedrock and macroclimate. For a more complete description of the study site see le Roux et al. (2013a).

(Insert Figure 1 here)

The biomass samples were collected in July 2011 during peak growing season. All living aboveground vascular biomass was collected from a randomly located 20 x $20 \mathrm{~cm}$ subplot within 
each $1 \mathrm{~m}^{2}$ cell. The biomass samples were dried at $65{ }^{\circ} \mathrm{C}$ for 48 hours and then weighed (Sartorius PT3100, accuracy $0.1 \mathrm{~g}$ ). Vascular plant cover was visually estimated in each cell and median vegetation height measured (excluding graminoids due to their disproportionate height : biomass ratio). Vegetation volume was calculated as the product of plant cover and vegetation median height.

Soil moisture was determined on three occasions during mid-summer with a FieldScout TDR 300 moisture meter (FieldScout TDR 300, Spectrum Technologies, Plainfield, USA; using $7.5 \mathrm{~cm}$ sensor rods), recording the mean of three measurements in each cell. The correlation between the different sampling events was high $(\mathrm{r}>0.88)$ and so the mean of all measurements was used in the analysis. Soil temperature was measured at $10 \mathrm{~cm}$ depth on two occasions (mid and late summer), using a digital thermometer (TFX 392 SKW-T thermometer, Ebro Electronic, Ingolstadt, Germany). From each grid 18 measurements were taken at $4 \mathrm{~m}$ intervals, with the resulting values interpolated for all cells with the interp.surface command in the fields package (Furrer et al. 2011), using R statistical software (R Development Core Team 2011).

In late summer soil samples were collected from the same locations where soil temperature was measured. These samples were air dried and subsequently analysed to determine soil $\mathrm{pH}$ and calcium content in the Laboratory of Geosciences and Geography (University of Helsinki) following the standardized ISO 10390 and ISO 17294-2 procedures (Nham 2010). As for soil temperature, results were interpolated to all other cells.

Local topography (i.e. mesotopography) was classified on a 10-point scale, following the methods of Bruun et al. (2006; see also Billings 1973, Walker et al. 2001, le Roux and Luoto 2014) where the lowest value (1) represents the bottom of a depression and the highest value (10) a ridge top. The end-points of this gradient both represent extreme environmental conditions. Exposed ridge positions have lower winter temperatures, higher mechanical stress (due to wind-blown ice crystals), and more variable water availability, while sheltered depressions have short snow-free periods (i.e. limited growing season length; Bruun et al. 2006). Slope and aspect were measured for each cell and maximum potential annual solar radiation (i.e. assuming clear sky conditions, $\mathrm{MJ} \mathrm{cm}^{-2}$ $\mathrm{a}^{-1}$ ) was calculated following McCune \& Keon (2002).

Geomorphological processes were recorded as the percent cover of six different geomorphologic processes - solifluction, cryoturbation, deflation, nivation, fluvial accumulation and erosion - in each cell by visually measuring the area affected by each process (following the method of Hjort and Luoto 2009). All investigations were performed by the same geomorphologist, who focused 
only on ESP (earth surface process) variables, to ensure independence of the botanical and geomorphological data. The activity of cryoturbation (soil frost processes), deflation (wind-driven erosion) and solifluction (gravity-driven down-slope soil creep) were defined based on observations of topsoil material (focusing on sorting of the substrate, the absence of fine sediment, and the presence of soil lobes perpendicular to the slope, respectively). Fluvial processes were similarly quantified, paying particular attention to soil textural properties, with their contributions combined into a single variable representing water-driven soil erosion and accumulation. Nivation (processes related to long-lasting snow patches) was measured from the depth of snow cover remaining in early/mid summer, and confirmed by observations of the temporal patterns of snowmelt (le Roux and Luoto, 2014). The geomorphological processes were combined for the analysis into three groups: frost-related processes (solifluction and cryoturbation), wind-related processes (deflation and nivation), and fluvial processes (erosion and accumulation). The influence of herbivory was not considered in the present analyses for two reasons; 1) this would add considerable further complexity to this research, and 2) herbivores have previously been shown to have relatively small impacts on vegetation properties in this study design (le Roux et al. 2013a).

\section{Statistical analyses}

To model the relationship between biomass and topographic, soil and geomorphological variables, generalized estimating equations models (GEEs, see Carl and Kühn 2007) were used to conduct variation partitioning (Borcard et al. 1992). GEEs are an extension of generalized linear models that allow the spatial non-independence of observations to be incorporated into analyses, and perform better than many other techniques for spatially-referenced data (Carl and Kühn 2007, Dormann et al. 2007). The data were analysed assuming a Gaussian distribution of errors for biomass, vegetation height and vegetation volume, and a binomial distribution of errors for vegetation cover. Prior to analysis biomass and vegetation volume were log-transformed and vegetation height was square root-transformed. To account for the spatial structure in the data, a fixed correlation structure was used to model spatial dependency in GEEs (following Carl and Kühn 2007; method also described in Hardin and Hilbe 2003, Dormann et al. 2007). The fixed correlation structure used in the GEE models was parameterized from the spatial autocorrelation observed in the residuals of the corresponding GLM, by fitting a negative exponential curve to residual autocorrelation over distance lags shorter than the distance class of the first non-significant autocorrelation value (see le Roux et al. 2013b for details). Because preliminary analyses showed that spatial autocorrelation was negligible between the six grids, points from separate grids were considered as independent. Thus a fixed correlation structure was modelled for each grid, allowing for the decay in spatial 
dependence to vary between grids. The analysis was conducted using the gee function from the geepack library (Højsgaard et al. 2005) in the statistical package R (R Development Core Team 2011), and was implemented using a modification of Carl and Kühn's (2007) GEE function.

Following a best subsets regression approach, all combinations of predictor variables were modelled. Both linear and second-order polynomial terms were included for each predictor variable to model potentially non-linear relationships. Initial analyses showed that multicollinearity between predictor variables within each variable group was minimal (maximum variation inflation factor $=$ 1.9; Fox \& Monette 1992), and therefore all predictors were retained for subsequent modelling. Models were ranked by the quasi-likelihood-under-the-independence-model information criterion (QIC, the GEE-equivalent of the Aikaike's Information Criterion; Pan 2001), calculated using a modification of the code outlined by Kraan et al. (2010) (see also Burnham and Anderson 1998), with the best fit model identified as having the lowest QIC value. Models containing second-order polynomial terms were only retained if each polynomial term's linear equivalent was also present in the model.

Variation partitioning was used to quantify the unique and shared contributions of the predictor variable groups and the total explanatory power of the models (Borcard et al. 1992). First, the best model within each group of explanatory variables (topography, soil and geomorphology) was determined (using GEEs, as detailed above). Second, all combinations of the three best models were analysed (i.e. modelling biomass as a function of the variables selected by, e.g., the best topography model and the best soil model). Finally, the variance explained by the full model (the variables selected by the best topography model, the best soil model and the best geomorphology model) was partitioned between the three predictor variable groups; creating eight fractions: (a) unique effect of soil, (b) unique effect of topography, (c) unique effect of geomorphology; and variation due to the shared effects of (d) soil and topography, (e) soil and geomorphology, (f) topography and geomorphology and (g) all the three variable groups; and (h) the unexplained variation. The procedure for variation partitioning with three explanatory matrices has been described in detail by Anderson \& Gribble (1998) and Heikkinen et al. (2004).

\section{Results}

The sampled grids included areas with differing conditions regarding to soil properties, topography and geomorphological activity, as well as variation in the amount of aboveground biomass (Table 1, Fig 2). Of the non-destructive biomass estimates, vegetation volume was most strongly correlated with the observed biomass (Spearman's rank correlation $=0.662, \mathrm{p}<0.001$ ), and vegetation height 
the most weakly correlated. Overall the correlations between all the biomass variables were relatively high, with the weakest correlation between vegetation cover and height (Table 2, Fig 3).

(Insert Fig 2 and 3 and Tables 1 and 2 here)

The best GEE models of biomass included all the variables except the second order terms of temperature and $\mathrm{pH}$, the best vegetation volume model excluded only the second-order term for fluvial processes, while the best vegetation height model excluded slope and the second order term of solar radiation. (Table 3; selected univariate relationships shown in Fig. 4). By contrast, the best model for vascular cover included all the variables and their second-order polynomial terms (Table $3)$.

(Insert Table 3 and Figure 4 here)

Variation partitioning revealed that soil variables have the largest unique contribution to explain variation in biomass, while topography had the smallest independent effect (Fig. 5). This pattern was consistent for biomass, vegetation volume and cover, but differed for vegetation height (where geomorphology had the strongest independent effect and soil properties the weakest). The amount of unexplained variation was close to $50 \%$ for vegetation volume and vegetation height, slightly lower for biomass sample and remarkably lower for vascular cover. A negative shared contribution of two variable groups (as seen in Fig. 5) indicates that strong collinearity between predictors in the different variable groups. As a result, less variation is explained when the two groups of variables are included together than is expected based on their effects in isolation (Chevan and Sutherland 1991).

(Insert Figure 5 here)

\section{Discussion}

Considerable spatial variation was observed in plant biomass, as has previously been reported for arctic and alpine areas (Fisk et al. 1998, Fletcher et al. 2010), with this fine scale heterogeneity strongly correlating with components of the abiotic environment. All three groups of abiotic predictors (soil properties, geomorphological processes, topography) contributed to explaining variation in biomass, reflecting the multivariate nature of the environmental constraints on plant productivity (in agreement with, e.g., Gould et al. 2003, Berdanier and Klein 2011). This pattern is likely to hold true in other areas of low biomass and similar climates in arctic and alpine environments in northern Europe (Kjelvik and Kärenlampi 1975, Jonasson 1982, Kyllönen 1988, Campioli et al. 2009) and North America (e.g. Walker et al. 1994, Fisk et al. 1998). 
Our results indicate that fine scale variation of vegetation biomass is mainly driven by soil properties, in agreement with previous studies that have shown the influence of these abiotic characteristics (Walker et al. 1994, Fisk et al. 1998, Berdanier and Klein 2011). Soil moisture was most strongly related to biomass, with the highest biomass values at the areas of intermediate moisture (Tables 3 and S1, Fig. 4), which supports the findings in earlier studies (Litaor et al. 2008, Berdanier and Klein 2011). Calcium content showed similar effects on biomass as soil moisture, although the correlation was much weaker (Table S1). Soil pH and temperature were also weakly related to biomass, but showed inconsistent relationships with biomass and the three biomass surrogates. The results suggest that soil resources (e.g. moisture, energy and nutrients) are more important drivers of biomass than disturbance processes (i.e. geomorphology) or landform position and orientation (i.e. topography), highlighting their importance under changing environmental conditions (e.g. rising temperatures increasing nutrient availability; Chapin et al. 2005).

Geomorphological processes generally did not explain as much variation in biomass as soil properties, but were particularly important for vegetation height. Our study provides empirical evidence that geomorphological processes affect vegetation structure and biomass, with geomorphologic activity decreasing arctic-alpine plant biomass, probably through mechanical disturbance (Jonasson 1986, le Roux and Luoto 2014). The effect of geomorphology was the strongest for vegetation height which may be explained by the fact that generally taller woody plants are more sensitive to disturbance and soil instability (Jonasson 1986, Haugland and Beatty 2004, Manninen et al. 2011). For vegetation height the shared effects of geomorphology and topography are also strong (Fig. 4), which may be due to snow cover being linked to topography and to woody plants responding positively to increased snow cover (Wahren et al. 2005, Wipf and Rixen 2010). Thus, in agreement with previous studies, investigating the effects of geomorphological processes on arctic-alpine vegetation have offered evidence that plant communities are affected by different earth surface processes (Malanson et al. 2012, le Roux and Luoto 2014).

While many abiotic and biotic characteristics are strongly related with local topography, our results suggest that the importance of mesotopography to vascular biomass is largely due to its indirect effect through soil properties and physical disturbances caused by geomorphological processes (see Hjort and Luoto 2009, le Roux and Luoto 2014). Topography affects the soil properties mainly by controlling fluvial processes and snow distribution which, in turn, affect soil moisture, temperature and growing season length (Taylor and Seastedt 1994, Walker et al. 1993, Fisk et al. 1998, Walker et al. 2001). Consequently, local topography, by controlling snow accumulation and drainage, 
affects arctic-alpine plant patterns, including for example species regrowth after disturbance (Evju et al. 2012). However, fine scale soil characteristics appear to be stronger predictors of biomass than more distally related topography variables. Nonetheless, as topography can be easily measured (including by remote sensing techniques) and does contribute to explaining some additional heterogeneity in biomass, this group of variables may represent a simple way to refine biomass models based on soil properties and earth surface processes.

From an applied perspective, the results highlight that vegetation volume is a useful surrogate of biomass as there is strong and significant correlation between the two variables. This supports the use of non-destructive methods in estimating biomass since both variables have similar responses to abiotic drivers. For vegetation cover, the amount of explained deviation is very low compared with the results for biomass samples and therefore its use as an approximation of biomass can be less appropriate than the use of vegetation volume. Consequently, these results suggest that vegetation volume could be used successfully as an estimate for biomass in arctic-alpine areas. This is particularly important finding in areas with low vegetation growth or highly sensitive species, where destructive sampling could conflict with vegetation monitoring programmes or strict conservation regulations.

The observed positive correlation between air temperature and productivity at high latitudes (Walker et al. 2003, Elmendorf et al. 2012), indicates a clear impact of climate warming on plant productivity. However, since local abiotic conditions strongly affect biomass and may also be affected by changing climatic conditions, the landscape cannot be considered as a homogenous background against which climate change will act. Indeed, through the cascading effects of local soil properties and earth surface processes, the impact of rising air temperatures could be strongly mediated by local abiotic heterogeneity. For example, increasing temperatures can lead to greater nutrient availability and changes in frost-related disturbance, with all of these environmental conditions affecting plant productivity in some manner (Chapin et al. 2005, Macias-Fauria and Johnson 2013). Thus, predictions of changes in biomass at local to regional levels cannot be based solely on broad scale climate scenarios.

\section{Conclusions}

In arctic-alpine tundra the variation in vegetation biomass is largely driven by the fine scale heterogeneity of the abiotic environment. The most important drivers of aboveground biomass are soil properties and especially soil moisture. Plant biomass is also effected by geomorphological processes that typically decrease the amount of biomass, mostly through mechanical disturbance. 
The effect of local topography on vegetation biomass is largely indirect and it has little independent influence on biomass after soil properties and geomorphology have been taken into account. All in all, our results indicate that fine scale environmental variation has to be taken into account more carefully when modelling vegetation biomass in arctic-alpine conditions. Even though climatic conditions are fundamental drivers of biomass, their effects are filtered through local abiotic conditions which may strongly mediate plant responses to changing temperature and precipitation regimes. Therefore, where data relating to local environmental conditions are available, these should be included in analyses of vegetation biomass patterns to improve estimates of the current biomass patterns and predictions of their future changes.

\section{Acknowledgements}

We acknowledge funding from the Academy of Finland (Project Number 1140873), and thank A. Kulonen, H. Mod and A. Niskanen for helping collect the data and J. Virkanen for soil analyses.

\section{Susanne Suvanto}

Vantaa Research Unit, Finnish Forest Research Institute, P.O. Box 18, 01301 Vantaa, Finland E-mail: susanne.suvanto@metla.fi

Peter C. le Roux

Department of Plant Science, University of Pretoria, 0028, Pretoria, South Africa

E-mail:peter.leroux@up.ac.za

\section{Miska Luoto}

Department of Geosciences and Geography, University of Helsinki

P.O. Box 64, FI-00014 University of Helsinki, Finland

E-mail:miska.luoto@helsinki.fi

\section{References}

Anderson, M.J. and N.A. Gribble, 1998. Partitioning the variation among spatial, temporal and environmental components in a multivariate data set. Australian Journal of Ecology $23,158-167$.

Axmanová, I., Tichý L., Fajmonová, Z., Hájková, P., Hettenbergerová, E., Li, C.-F., Merunková, K., Nejezchlebová, M., Otýpková, Z., Vymazalová, M. and Zelený, D., 2012. Estimation of herbaceous biomass from species composition and cover. Applied Vegetation Science 15, 580-589. 
Berdanier, A.B. and Klein, J.A., 2011. Growing season length and soil moisture interactively constrain high elevation aboveground net primary production. Ecosystems 14, $963-$ 974.

Bhatt, U.S., Walker, D.A., Raynolds, M.K., Comiso, J.C., Epstein, H.E., Jia, G.S., Gens, R., Pinzon, J.E., Tucker, C.J., Tweedie, C.E. and Weber, P.J., 2010. Circumpolar Arctic undra vegetation change is linked to sea ice decline. Earth Interactions 14, 1-20.

Billings, W.D., 1973. Arctic and alpine vegetations: Similarities, differences, and susceptibility to disturbance. Bioscience 23, 697-704.

Bobek, B. and Bergström, R., 1978. A rapid method of browse biomass estimation in a forest abitat. Journal of Range Management 31, 456-458.

Borcard, D., Legendre, P. and Drapeau, P., 1992. Partialling out the spatial component of ecological ariation. Ecology 73, 1045-1055.

Bruun, H.H., Moen, J., Virtanen, R., Grytes, J.-A., Oksanen, L. and Angerbjörn, A., 2006. Effects of altitude and topography on species richness of vascular plants, bryophytes and lichens in alpine communities. Journal of Vegetation Science 17, 37-46.

Burnham, K.P., Anderson, D.R., 1998. Model Selection and Inference: a Practical Information Theoretic Approach. Springer, New York.

Callaghan, T.V., Björn, L.O., Chernoc, Y., Chapin, T:, Christensen, T.R., Hunstley, B., Ims, R.A., Johansson, M., Jolly, D., Jonasson, S., Matveyeva, N., Panikoc, N., Oechel, W., Shaver, G., Schaphoff, S., Sitch, S. and Zöckler, C., 2004. Synthesis of effects in four arctic subregions. AMBIO 33, 469-473. doi:/10.1579/0044-7447-33.7.469

Campioli, M., Michelsen, A., Demey, A., Vermeulen, A., Samson, R. and Lemeur, R., 2009. Net primary production and carbon stocks for subarctic mesic-dry tundras with contrasting microtopography, altitude and dominant species. Ecosystems 12, 760-776.

Carl, G. and Kühn, I., 2007. Analyzing spatial autocorrelations in species distributions using Gaussian and logit models. Ecological Modelling 207, 159-170.

Chapin, F., Sturm M., Serreze, M., McFadden, J., Key, J., Lloyd, A., McGuire, A., Rupp, T., Lynch, A., Schimel, J., Beringer, J., Chapman, W., Epstein, H., Euskirchen, E., Hinzman, L., Jia, G., Ping, C., Tape, K., Thompson, C., Walker, D., Welker, J., 2005: Role of the land-surface changes in arctic summer warming. Science 310: 657-660. Chen, W., Li, J., Zhang, Y., Zhou, F., Koehler, K., Leblac, S., Fraser, R., Olthof, I., Zhang, Y. and Wang, J., 2009. Relating biomass and leaf area index to non-destructive measurements in order to monitor changes in arctic vegetation. Arctic 62: 3, 281-294. 
Chevan, A. and Sutherland, M., 1991. Hierarchical partitioning. The American Statistician 45, 90 96.

Dormann, C.F., McPherson, J.M., Araújo, M.B., Bivand, R., Bolliger, J., Carl, G., Davies, R.G., Hirzel, A., Jetz, W., Kissling, D., Kühn, I., Ohlemüller, R., Peres-Neto, P.R., Reineking, B., Schröder, B., Schurr, F.M. and Wilson, R., 2007. Methods to account for spatial autocorrelation in the analysis of species distributional data: a review. Ecography 30, 609-628.

Elmendorf, S.C., Henry, G.H.R., Hollister, R.D., Björk, R.G., Boulanger-Lapointe, N., Cooper, E.J., Cornelissen, J.H.C., Day, T.A., Dorrepaal, E., Elumeeva, T.G., Gill, M., Gould, W.A., Harte, J., Hik, D.S., Hofgaard, A., Johnson, D.R., Johnstone, J.F., Jónsdóttir, I.S., Jorgenson, J.C., Klanderud, K., Klein, J.A., Kohl, S., Kudo, G., Lara, M., Lévesque, E., Magnússon, B., May, J.L., Mercado-Díaz, J.A., Michelsen, A., Molau, U., H. Myers-Smith, I., Oberbauer, S.F., Onipchenko, V.G., Rixen, C., Schmidt, N.M., Shaver, G.R., Spasojevic, M.J., Pórhallsdóttir, P.E., Tolvanen, A., Troxler, T., Tweedie, C.E., Villareal, S., Wahren, C.-H., Walker, X., Webber, P.J., Welker, J.M. and Wipf, S., 2012. Plot-scale evidence of tundra vegetation change and links to recent summer warming. Nature Climate Change 2: 453-457.

Evju, M., Hagen, D. and Hofgaard, A., 2012. Effects of disturbance along snow pack gradients in alpine habitats. Plant Ecology 213, 1345-1355.

Epstein, H.E., Raynolds, M.K., Walker, D.A., Bhatt, U.S., Tucker, C.J. and Pinzon, J.E., 2012. Dynamics of aboveground phytomass of the circumpolar Arctic tundra during the past three decades. Environmental Research Letters 7, 015506. doi:10.1088/17489326/7/1/015506

Fisk. M.C., Schmidt, S.K. and Seastedt, T.R., 1998. Topographic patterns of above- and belowground production and nitrogen cycling in alpine tundra. Ecology 79, 2253-2266.

Fletcher, B.J., Press, M. C., Baxter, R. and Phoenix, G.K., 2010. Transition zones between vegetation patches in a heterogeneous Arctic landscape: how plant growth and photosynthesis change with abundance at small scales. Oecologia 163, 47-56.

Fox, J. and Monette, G., 1992. Generalized collinearity diagnostics. Journal of the American Statistical Association 87, 178-183.

Furrer, R., Nychka, D. and Sain, S., 2011. fields: Tools for spatial data (R package). 
ould, W.A., Raynolds, M. and Walker, D.A., 2003. Vegetation, plant biomass, and net primary productivity patterns in the Canadian Arctic. Journal of Geophysical Research 108, D2, 8167. doi:10.1029/2001JD000948.

Hardin, J.W. and Hilbe, J.M., 2003. Generalized estimating equations. Chapman and Hall/CRC, Boca Raton, Florida, USA.

Haugland, J.E. and Beatty, S.W., 2005. Vegetation establishment, succession and microsite frost disturvance on glacier forelands within patterned ground chronosequences. Journal of Biogeography 32, 145-153.

eikkinen, R.K., Luoto, M., Virkkala, R. and Rainio, K., 2004. Effects of habitat cover, landscape structure and spatial variables on the abundance of birds in an agricultural-forest mosaic. Journal of Applied Ecology 41, 824-835.

Hjort, J. and Luoto, M., 2009. Interaction of geomorphic and ecologic features across altitudinal zones in a subarctic landscape. Geomorphology 112, 324-333.

Højsgaard, S., Halekoh, U. and Yan, J., 2006. The R Package geepack for Generalized Estimating Equations. Journal of Statistical Software 15: 2, 1-11.

ISO 10390. Soil quality-Determination of pH. Internal Organization for Standardization. 6 p.

SO 17294-2. Water quality-Application of inductively coupled plasma mass spectromety (ICPMS). Part 2:Determination of 62 elements. Internal Organization for Standardization. $22 \mathrm{p}$.

Jonasson, S., 1982. Organic matter and phytomass on three north Swedish tundra sites, and some connections to adjacent tundra areas. Holarctic Ecology 5, 367-375.

Jonasson, S., 1986. Influence of frost heaving on soil chemistry and on the distribution of plant growth forms. Geografiska Annaler, Series A. Physical Geography 68, 185-195.

Kjelvik, S. and Kärenlampi, L., 1975. Plant biomass and primary production of Fennoscandian subarctic and subalpine forests and of alpine willow and heath ecosystems. Ecological Studies 16, 111-120.

raan, C., Aarts, A., van der Meer, J. and Piersma, T., 2010. The role of environmental variables in structuring landscape-scale species distributions in seafloor habitats. Ecology 91, $1583-1590$.

Krebs, C.J., Danell, K., Angerbjörn, A., Agrell, J., Berteaux, D., Bråthen, K.A., Danell, Ö., Erlinge, S., Fedorov, V., Fredga, K., Hältén, J., Högstedt, G., Jónsdóttir, I.S., Kenney, A.K., Kjellén, N., Nordin, T., Roininen, H., Svensson, M., Tannerfeldt, M. and Wiklund, C., 2003. Terrestrial trophic dynamics in the Canadian Arctic. Canadian Journal of Zoology 62, 281-294. 
Kullman, L., 2010. A richer, greener and smaller alpine world: Review and projection of warminginduced plant cover change in the Swedish Scandes. AMBIO 39, 159-169.

Kyllönen. H. (1988) Alpine and subalpine vegetation at Kilpisjärvi. Finnish Lapland. Distribution of biomass and net production and annual variations in biomass. Acta Universitatis Ouluensis A 202. 78 p.

le Roux, P.C. and Luoto, M., 2014. Earth surface processes drive the richness, composition and occurrence of plant species in an arctic-alpine environment. Journal of Vegetation Science 25, 45-54..

le Roux, P.C., Lenoir, J., Pellisier, L., Wisz, M. and Luoto, M., 2013a. Horizontal, but not vertical, biotic interactions affect fine-scale plant distribution patterns in a low energy system. Ecology 94: 671-682..

le Roux, P.C., Ramaswiela, T., Kalwij, J.M., Shaw, J.D., Ryan, P.G., Treasure, A.M., McClelland, G.T.W., McGeoch, M.A. and Chown, S.L., 2013b. Human activities, propagule pressure and alien plants in the sub-Antarctic: Tests of generalities and evidence in support of management. Biological Conservation 161: 18-27.

Litaor, M.I., Williams, M. and Seastedt, T.R., 2008. Topography controls on snow distribution, soil moisture, and species diversity of herbaceous alpine vegetation, Niwot Ridge, Colorado. Journal of Geophysical Research 113: G2, 1-10.

Macias-Fauria, M. and Johnson, E.A., 2013. Warming-induced upslope advance of subalpine forest is severely limited by geomorphic processes. Proceedings of the National Academy of Sciences USA (in press, preprint online). doi: 10.1073/pnas.1221278110.

Malanson, G.P., Bengtson, L.E. and Fagre, D.B., 2012. Geomorphic determinants of species composition of alpine tundra, Glacier National Park, U.S.A. Arctic, Antarctic and Alpine Research 44, 197-209.

Manninen, O.H, Stark, S. Kytöviita, M.-M. and Tolvanen, A., 2011. Individual and combined effects of disturbance and $\mathrm{N}$ addition on understorey vegetation in a subarctic mountain birch forest. Journal of Vegetation Science 22, 262-272.

McCune, B. and Keon, D., 2002. Equations for potential annual direct incident radiation and heat load. Journal of Vegetation Science 13, 603-606.

Muukkonen, P., Mäkipää, R., Laiho, R., Minkkinen, K., Vasander, H. and Finér, L., 2006. Relationship between biomass and percentage cover in understorey vegetation of boreal coniferous forests. Silva Fennica 40, 231-245.

Nham, T.T. (2010). Analysis of soil extracts using the Varian 725-ES. ICP OES Application note 34. 
Pan, W., 2001. Akaike's information criterion in generalized estimating equations. Biometrics 57, $120-125$.

Pouliot, D., Latifovic, R. and Olthof, I., 2009. Trends in vegetation NDVI from $1 \mathrm{~km} \mathrm{AVHRR} \mathrm{data}$ over Canada for the period 1985-2006. International Journal of Remote Sensing 30, 149-168.

R Development Core Team, 2011. R: A language and environment for statistical computing. $\mathrm{R}$ Project for Statistical Computing. Vienna, Austria <http://www.r-project.org>

Redjadj, C., Duparc, A., Lavorel, S., Grigulis, K., Bonenfant, C., Maillard, D., Saïd, S. and Loison, A., 2012. Estimating herbaceous plant biomass in mountain grasslands: a comparative study using three different methods. Alpine Botany 122, 57-63.

Röttgermann, M., Steinlein, T., Beyschlag, W. and Dietz, H., 2000. Linear relationships between aboveground biomass and plant cover in low open herbaceous vegetation. Journal of Vegetation Science 11, 145-148.

Shaver, G.R., Laundre, J.A., Giblin, A.E. and Nadelhoffer, K.J., 1996. Changes in Live Plant Biomass, Primary Production, and Species Composition along a Riverside Toposequence in Arctic Alaska, U.S.A. Arctic and Alpine Research 28, 363-379.

Shaver, G.R., Street, L.E., Rastetter, E.B., van Wijk, M.T. and Williams, M., 2007. Functional convergence in regulation of net $\mathrm{CO}_{2}$ flux in heterogeneous tundra landscapes in Alaska and Sweden. Journal of Ecology 95, 802-817.

Sitch, S., McGuire, A.D., Kimball, J., Gedney, N., Gamon, J., Engstrom, R., Wolf, A., Zhuang, Q., Clein, J. and McDonald, K.C., 2007. Assessing the carbon balance of circumpolar arctic tundra using remote sensing and process modeling. Ecological Applications 17, $213-234$

Sturm, M., Racine, C. and Tape, K., 2001. Increasing shrub abundance in the Arctic. Nature 411, $546-547$.

Taylor, R.V. and Seastedt, T.R., 1994. Short- and long-term patterns of soil moisture in alpine tundra. Arctic and Alpine Research 26, 14-20.

Tsutsumi, M., Itano, S. and Shiyomi, M., 2007. Number of samples required for estimating herbaceous biomass. Rangeland Ecology \& Management 60, 447-452.

Virtanen, R., Luoto, M., Rämä, T., Mikkola, K., Hjort, J., Grytnes, J.-A. and Birks, H.J.B., 2010. Recent vegetation changes at the high-latitude tree line ecotone are controlled by geomorphological disturbance, productivity and diversity. Global Ecology and Biogeography 19, 810-821. 
Wahren, C.-H.A., Walker, M.D. and Bret-Harte, M.S., 2005. Vegetation responses in Alaskan arctic tundra after 8 years of summer warming and winter snow manipulation experiment. Global Change Biology 11, 53 -552. doi: 10.1111/j.1365-2486.2005.00927.x.

Walker, D.A., Epstein, H.E., Jia, G.J., Balser, A., Copass, C., Edwards, E.J., Gould, W.A., Hollingsworth, J., Knudson, J., Maier, H.A., Moody, A. and Raynolds, M.K., 2003. Phytomass patterns across a temperature gradient of the North American arctic tundra. Journal of Geophysical Research 113: G03S02. doi:10.1029/2007JG000555.

Walker, D.A., Halfpenny, C., Walker, M.D. and Wessman, C.A., 1993. Long-term studies of snowvegetation interactions. BioScience 43, 287-301.

Walker, D.A., Molenaar, J.G. and Billings, W.D., 2001. Snow-vegetation interactions in tundra environments. In Jones, H.G., Pomeroy, J., Walker, D.A. and Wharton, R. (eds): Snow Ecology. Cambridge University Press, Cambridge. 264-322.

Walker, M.D., Webber, P.J., Arnold, E.H. and Ebert-May, D., 1994. Effects of interannual climate variation on aboveground phytomass in alpine vegetation. Ecology 75: 2, 393-408.

Wipf, S. and Rixen, C., 2010. A review of snow manipulation experiments in Arctic and alpine tundra ecosystems. Polar Research 29, 95-109. doi:10.1111/j.17518369.2010.00153.x.

Manuscript Received 22 May, 2013 , revised and accepted 3 May, 2014 
Table 1. Summary of site characteristics across the six sampled grids $(n=960)$, showing the maximum, minimum and mean (median for $\mathrm{pH}$ ) values and standard deviations for response and predictor variables.

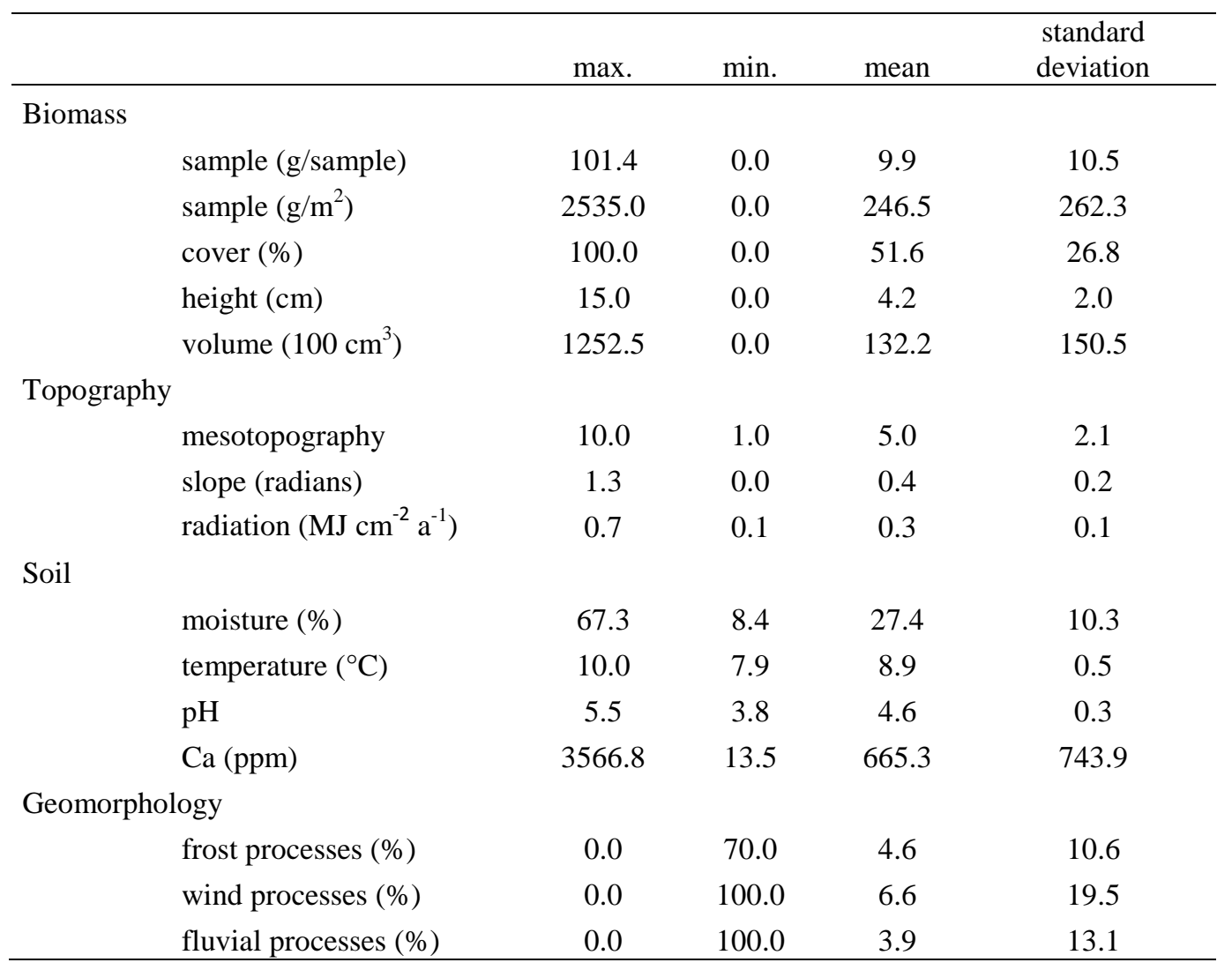


Table 2. Spearman rank correlation coefficients for the relationship between the biomass variables: sampled biomass, cover of vascular vegetation, median height of vegetation and vegetation volume (calculated as the product of vegetation cover and height). All correlations are significant at $\mathrm{p}<$ 0.001 .

\begin{tabular}{lccc}
\hline & sampled biomass & cover & height \\
\hline cover & 0.577 & & \\
height & 0.540 & 0.405 & \\
volume & 0.662 & 0.851 & 0.799 \\
\hline
\end{tabular}


Table 3. Best-fit GEE models for each predictor variable group (i.e. best fit models using only topography, soil or geomorphology variables).

\begin{tabular}{|c|c|c|c|c|}
\hline & $\begin{array}{c}\text { Sampled } \\
\text { biomass } \\
\text { coefficient }\end{array}$ & $\begin{array}{l}\text { Vegetation } \\
\text { volume } \\
\text { coefficient }\end{array}$ & $\begin{array}{l}\text { Vegetation } \\
\text { cover } \\
\text { coefficient }\end{array}$ & $\begin{array}{c}\text { Vegetation } \\
\text { height } \\
\text { coefficient }\end{array}$ \\
\hline intercept & -0.319 & 10.252 & 99.207 & -4.412 \\
\hline \multicolumn{5}{|l|}{ Topography } \\
\hline mesotopo & 0.107 & 0.047 & -0.017 & 0.081 \\
\hline mesotopo $^{2}$ & -0.011 & -0.006 & -0.003 & -0.012 \\
\hline slope & 0.233 & 0.720 & 1.918 & -- \\
\hline slope $^{2}$ & -0.047 & -0.600 & -1.558 & -- \\
\hline radiation & 4.155 & 2.050 & 7.714 & 0.610 \\
\hline radiation $^{2}$ & -3.994 & -2.074 & -8.274 & -- \\
\hline \multicolumn{5}{|l|}{ Soil } \\
\hline moisture & 0.089 & 0.032 & 0.128 & 0.008 \\
\hline moisture $^{2}$ & -0.001 & -0.001 & -0.002 & 0.000 \\
\hline temperature & -0.193 & -2.759 & -20.350 & 0.228 \\
\hline temperature $^{2}$ & -- & 0.152 & 1.115 & -0.014 \\
\hline $\mathrm{pH}$ & 0.091 & 1.167 & -6.112 & 2.064 \\
\hline $\mathrm{pH}^{2}$ & -- & -0.089 & 0.857 & -0.196 \\
\hline $\mathrm{Ca}$ & $9.60 \times 10^{-7}$ & $1.74 \times 10^{-4}$ & 0.001 & $1.12 \times 10^{-4}$ \\
\hline $\mathrm{Ca}^{2}$ & $-4.85 \times 10^{-9}$ & $-3.96 \times 10^{-8}$ & $-1.49 \times 10^{-7}$ & $-1.81 \times 10^{-9}$ \\
\hline \multicolumn{5}{|l|}{ Geomorphology } \\
\hline frost processes & -0.025 & -0.020 & -0.082 & -0.020 \\
\hline frost processes ${ }^{2}$ & $2.80 \times 10^{-4}$ & $2.05 \times 10^{-4}$ & 0.001 & $1.70 \times 10^{-4}$ \\
\hline wind processes & -0.017 & -0.012 & -0.022 & -0.012 \\
\hline wind processes ${ }^{2}$ & $1.60 \times 10^{-4}$ & $1.21 \times 10^{-4}$ & $4.00 \times 10^{-4}$ & $7.47 \times 10^{-5}$ \\
\hline fluvial processes & -0.021 & -0.006 & -0.016 & -0.020 \\
\hline fluvial processes ${ }^{2}$ & $2.25 \times 10^{-4}$ & -- & $2.00 \times 10^{-2}$ & $1.48 \times 10^{-4}$ \\
\hline
\end{tabular}

-- not included in the best model 
Figure 1. a) Sampled grids and the variation of mesotopography in the cells: color white represents value 10 (ridge top) and black value 1 (bottom of depression). Places and directions of photographs in Fig 2 are marked with black arrows. b) The location of the field site on mount Saana, indicated by the black rectangle and letter A. c) The location of the study area in north-western Finland, indicated by the black circle.

Figure 2. Photographs showing different conditions on the study area: a) an exposed and dry area with convex topography, b) high biomass area with Empetrum hermophroditum and Betula nana as dominant species c) local depression with low biomass. All photos were taken on 9 July 2012. Locations of the photographs can be seen in Fig 1.

Figure 3. The relationships between sampled biomass and the three non-destructive biomass estimates as scattergrams and loess lines.

Figure 4. The relationships between the four biomass variables and selected predictor variables from each variable group, as indicated by loess lines. Mesotopography presents the local topography on a 10-point scale, value 1 representing a bottom of a depression and value 10 a ridge top.

Figure 5. Variation partitioning for the four biomass variables. Variation in the response variables is partitioned between three groups of environmental variables: soil properties, topography and geomorphology. Sections a, b and c represent the unique effects of the predictor variable groups, while d, e, f and $g$ indicating shared effects. 


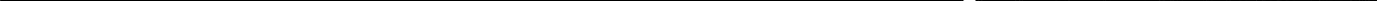




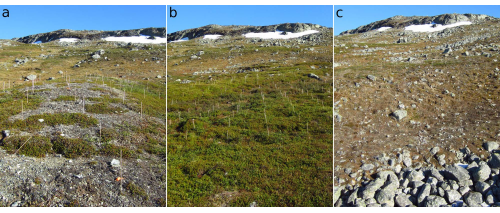




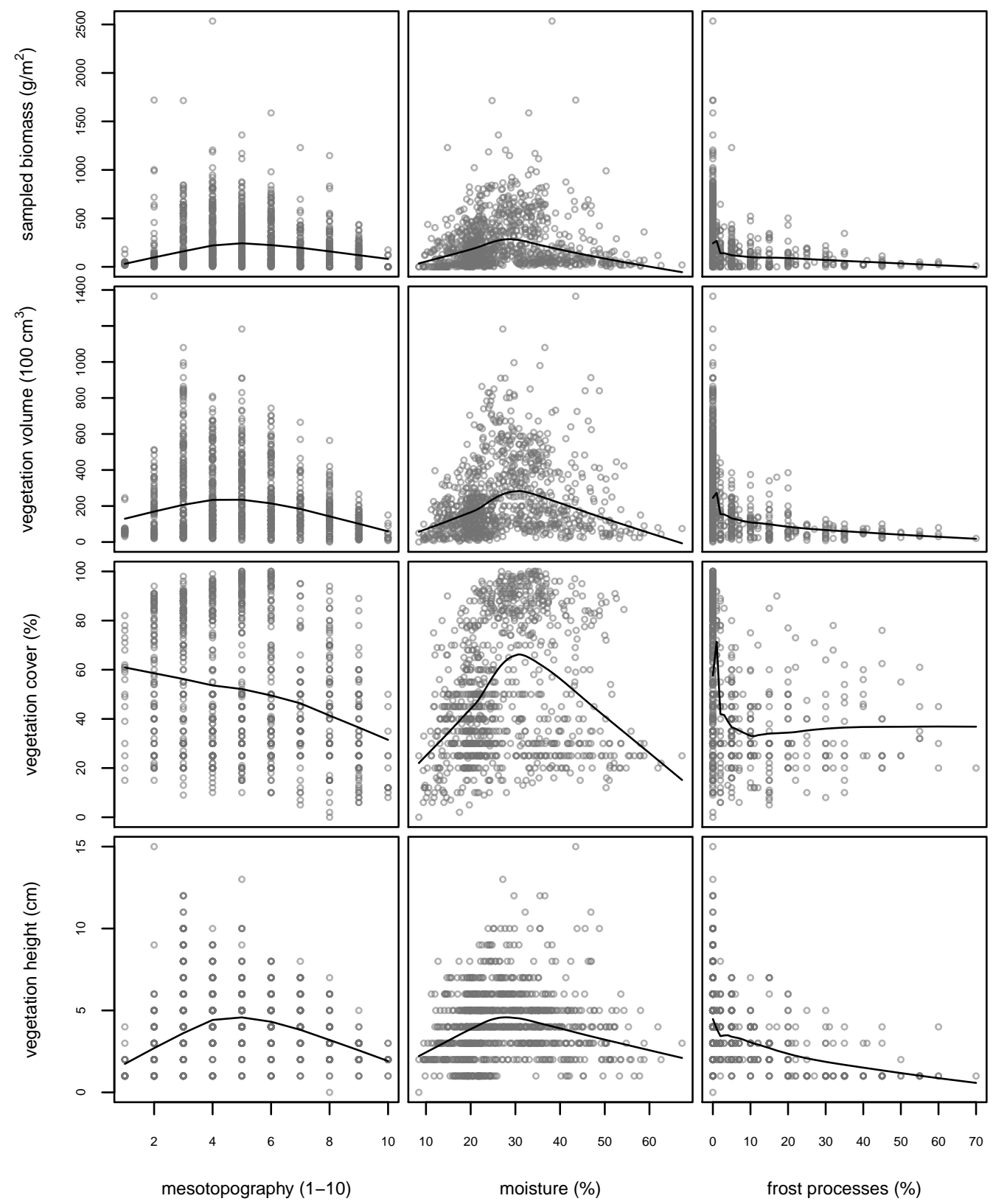




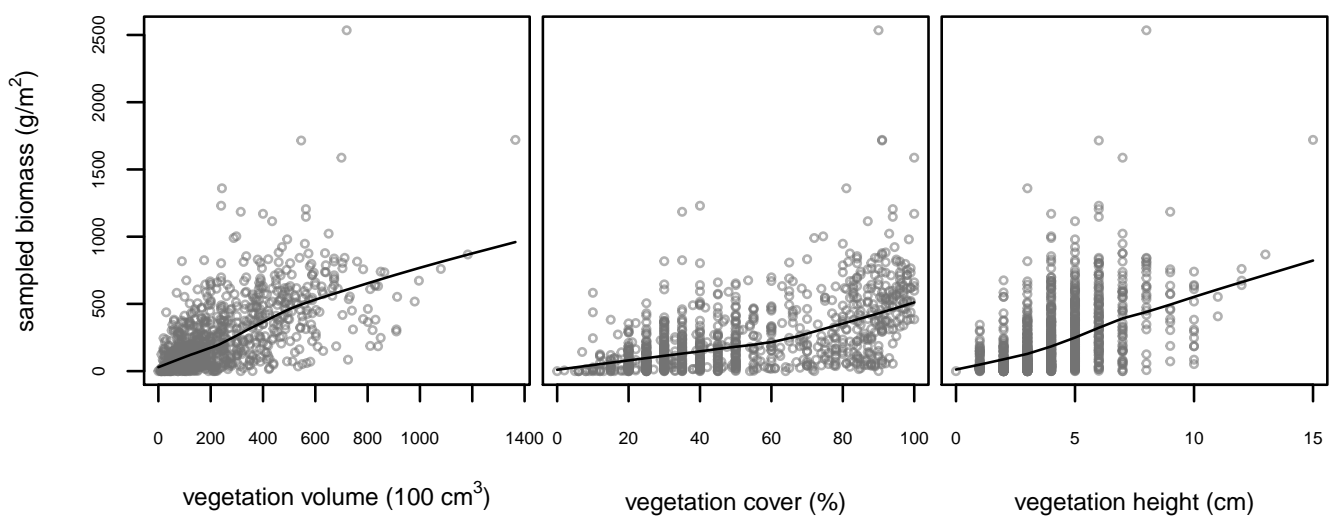


SAMPLED BIOMASS

Unexplained

67.11
VEGETATION VOLUME Unexplained

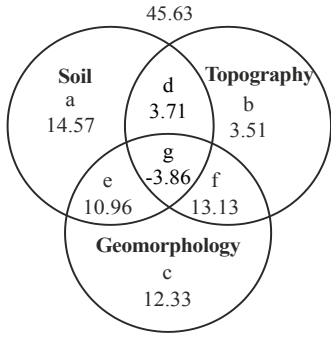

VEGETATION HEIGHT

Unexplained

\subsection{8}

\section{VEGETATION COVER}

Unexplained

88.84
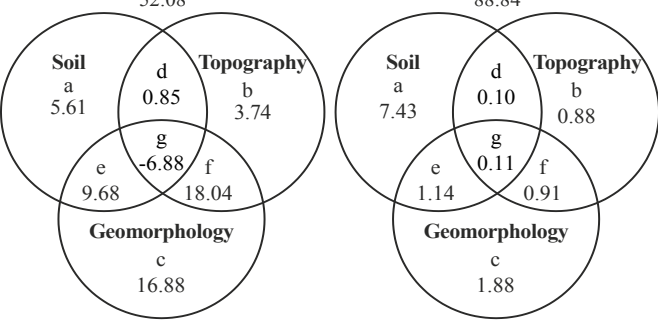